Gut, 1972, 13, 103-106

\title{
Intrajejunal volatile fatty acids in the stagnant loop syndrome
}

\author{
A. J. CHERNOV, W. F. DOE, AND D. GOMPERTZ \\ From the MRC Intestinal Malabsorption Research Group, Department of Medicine, Royal Postgraduate \\ Medical School, London
}

SUMMARY In the stagnant loop syndrome an abnormal anaerobic flora colonizes the small bowel. Anaerobic organisms are characterized by fermentation reactions leading to the production of volatile fatty acids. This paper describes the measurement of intrajejunal volatile fatty acid concentrations in 11 patients with the stagnant loop syndrome. Nine normal persons and 18 patients with gastrointestinal disease without intestinal stasis acted as controls. Acetate and propionate concentrations were greatly increased in the patients with the stagnant loop syndrome and returned to normal in those patients treated with antibiotics. The measurement of intrajejunal volatile fatty acid concentrations as an index of overgrowth of anaerobic organisms is discussed.

The production of volatile fatty acids by anaerobic fermentation reactions has been studied extensively in ruminant nutrition (Bryant, 1970). Recently the production of volatile fatty acids has also been investigated in the non-ruminant: Young, Manoharan, and Mickelsen (1970) have demonstrated that the production of volatile fatty acids by anaerobic bacteria in the caecum of the rat may contribute as much as $5 \%$ of the animal's energy requirements. Moore, Cato, and Holdeman (1969) have studied the production of volatile fatty acids by the normal anaerobic ficra which proliferates in the human large bowel. The small bowel, by contrast, contains relatively small numbers of bacteria. The organisms that are present are aerobic or facultatively anaerobic (Gorbach, Plaut, Nahas, Sparknebel, Weinstein, and Levitan, 1967). In the stagnant loop syndrome, however, the total number of anaerobic organisms is greatly increased, the viable anaerobic bacterial concentrations increasing from $10^{8}$ to $10^{9}$ organisms per ml (Drasar and Shiner, 1969; Tabaqchali, 1970). The presence of this extensive anaerobic flora suggested that excessive volatile fatty acid production might be a feature of this condition. In this study we have investigated the intrajejunal volatile fatty acid concentrations in patients with the stagnant loop syndrome, in normal persons, and in a control group of patients with gastrointestinal disease but no evidence of stagnation or bacterial overgrowth.

Received for publication 15 November 1971.

\section{Patients}

Thirty-eight subjects were studied and they were divided into three groups. The first group consisted of nine healthy controls. The second group included 11 patients with the stagnant loop syndrome (Table I). All the patients in this group had a demonstrable anatomical lesion to account for small bowel stagnation. All were shown to have malabsorption of fat and/or of vitamin $B_{12}$ and in 10 overgrowth by anaerobic bacteria had previously been demonstrated. The third group consisted of 18 patients with gastrointestinal disease but no radiological evidence of stagnation and no malabsorption secondary to bacterial overgrowth. This group included patients with Polya gastrectomy (5), Crohn's disease (4), coeliac disease (3), $\alpha$-chain disease (2), tropical sprue (1), diabetic enteropathy (1), a patient with malabsorption and subtotal villous atrophy not responsive to a gluten-free diet, and one patient with steatorrhoea of unknown cause.

\section{Methods}

COLLECTION OF JEJUNAL CONTENTS FOR ANALYSIS OF VOLATILE FATTY ACIDS

All subjects were prepared for jejunal intubation by an overnight fast. A sterile open-ended tube was used and was passed to a position between 5 and 15 $\mathrm{cm}$ past the ligament of Treitz. The position of the tip of this tube was checked fluoroscopically. Immediately after aspiration, samples of jejunal 


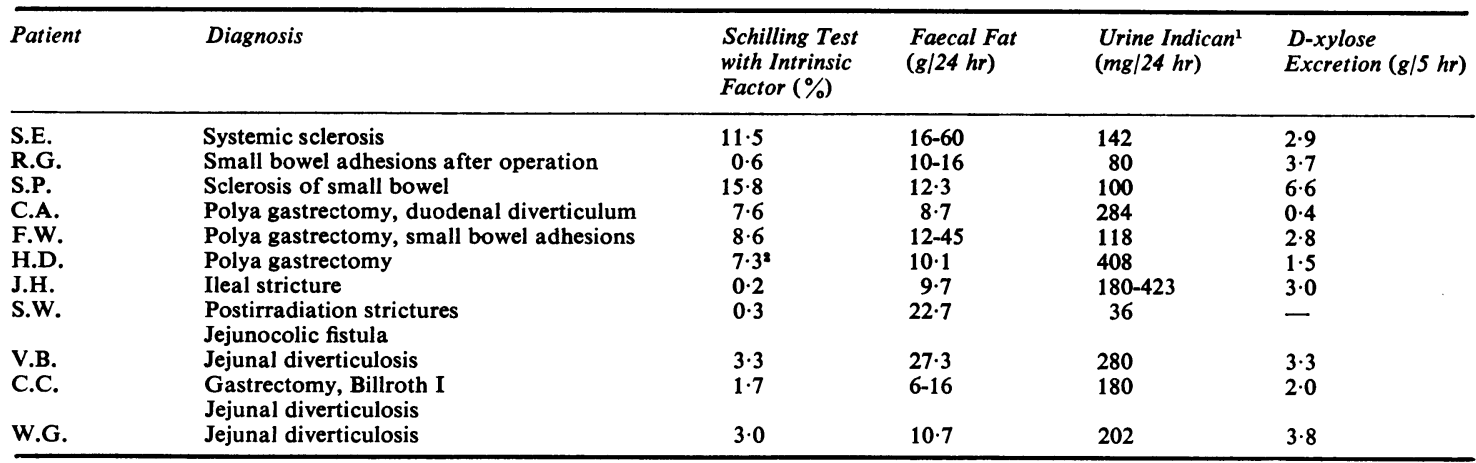

Table I Patients with the stagnant-loop syndrome

${ }^{1}$ Indican excretion, upper limit of normal $-92 \mathrm{mg} / 24$ hours.

contents were transferred to a deep freeze and $5 \mathrm{ml}$, adjusted to $p \mathrm{H} 2$ with $25 \% \mathrm{H}_{3} \mathrm{PO}_{4}$ and then maintained at $-20^{\circ} \mathrm{C}$ until analysis. steam distilled in a Markham still after the addition of Dow-Corning antifoam compound $\mathrm{H}$ 10. Two

ANALYSIS OF VOLATILE FATTY ACIDS IN hundred $\mathrm{ml}$ of distillate was collected, 3-methyl JEJUNAL JUICE valeric acid was added as an internal standard, and One ml samples of jejunal juice were diluted to the $p \mathrm{H}$ adjusted to between 8 and 9 with $0 \cdot 1 \mathrm{~N}$
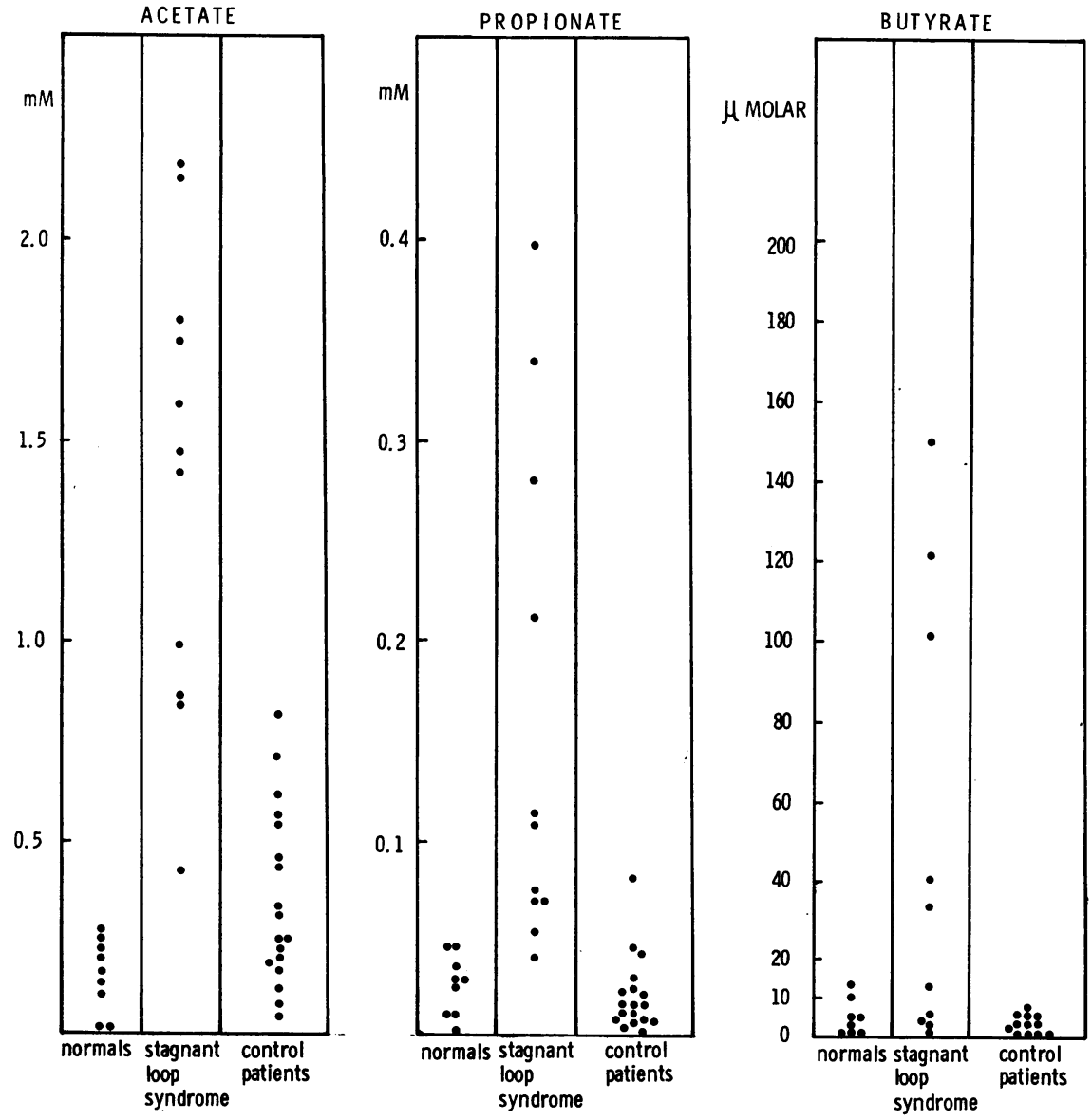

Fig. 1 Intrajejunal volatile fatty acid concentrations in normal persons, in patients with the stagnant-loop syndrome, and in patients with gastrointestinal disease without stagnation. 
$\mathrm{NaOH}$. The volume was reduced by boiling to $2-3$ $\mathrm{ml}$, and the sample finally reduced to dryness under nitrogen. Immediately before analysis the dry residue was dissolved in $100 \mu 125 \% \mathrm{H}_{3} \mathrm{PO}_{4}$. Approximately $1.5 \mu \mathrm{l}$ of this solution was used for gas chromatography. Analyses were performed using 5 -ft glass columns packed with $20 \%$ neopentylglycol adipate on $2 \%$ phosphoric-acid-treated celite at $130^{\circ}$. The injection zone was packed with uncoated Chromosorb $\mathbf{Q}$ and this was replenished regularly. The apparatus was a Pye 104 gas chromatograph with a flame ionization detector.

A standard mixture containing acetic, propionic, butyric, isobutyric, valeric, and isovaleric acids as well as the internal standard, 3-methyl valeric acid, was analysed daily to establish response ratios for each individual acid. All analyses were quantitated using peak height measurements. Blank analyses were performed daily to estimate the small amounts of acetate inevitably present in the distillate. The concentration of acetate in these blanks was reproducible and low compared with the concentrations present in jejunal aspirates, but was routinely subtracted from each analysis.

\section{Results}

\section{VOLATILE FATTY ACID CONCENTRATIONS}

The results in the three groups of subjects studied are shown in Figure 1. All samples contained acetate and propionate and most samples contained at least traces of butyrate. The concentrations of these three volatile acids were much higher in the jejunal aspirates from the patients with the stagnant loop syndrome than from normal persons or control patients (Fig. 1). The distribution of acetate, propionate, and butyrate concentrations in the three groups of patients was similar. Acetate accounted for $85-95 \%$ of the volatile acids present and propionate was present in one tenth to one twentieth of this concentration.

There was a clear distinction between acetate concentrations in aspirates from normal persons and the patients with the stagnant loop syndrome. Although the concentration of acetate in aspirates from patients with other gastrointestinal diseases extended to higher levels than in healthy persons, there was still an obvious distinction between the two groups of patients. A similar distribution of propionate concentrations was found. There was only one patient with the stagnant loop syndrome with a propionate concentration below $0.05 \mathrm{~m}$ molar and only one person of the combined normal person and control patient groups above this concentration. The distribution of butyrate concentrations is less clear; however the only persons with markedly raised butyrate concentrations were five patients with the stagnant loop syndrome.

\section{Effect of antibiotics}

The effects of antibiotics on volatile fatty acid concentrations were investigated in three patients (Fig. 2). Patient C.C. received neomycin for seven days, while S.E. and R.G. each received lincomycin $0.5 \mathrm{~g}$ twice daily for 14 days. Acetate and propionate concentrations fell in all three patients to levels that were in the normal range The concentrations of acetate and propionate in C.C. and R.G. fell to lower levels than would be expected in jejunal aspirates from normal persons. The butyrate
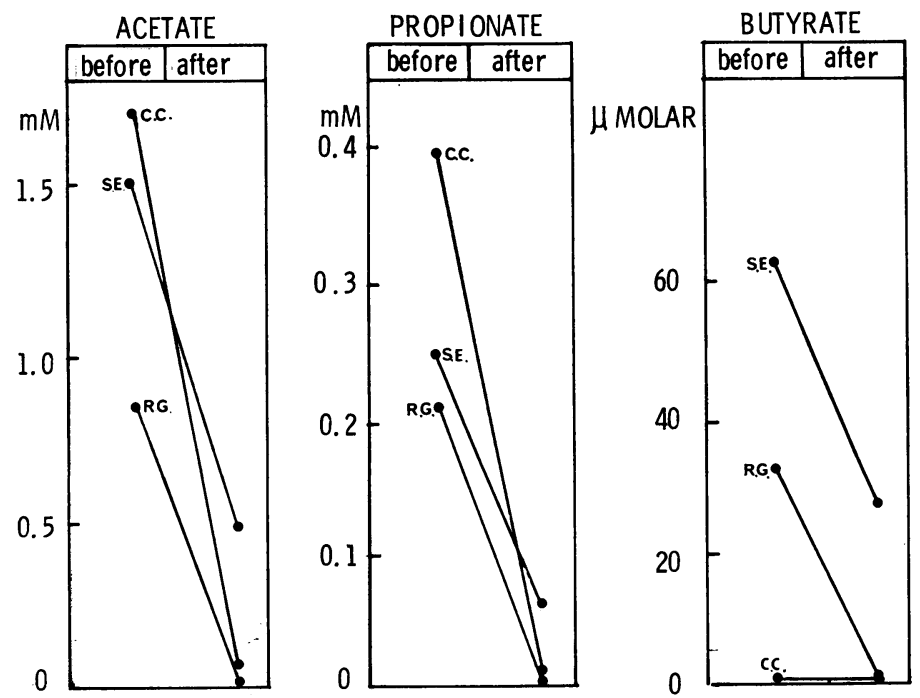

Fig. 2 The effect of antibiotics on intrajejunal volatile fatty acid concentrations. 
concentration in the two patients in whom it was raised before treatment also fell towards normal levels. The fall in volatile fatty acid concentrations in all three patients coincided with their clinical improvement and the return to normal of their absorption tests (Table II).

\begin{tabular}{lllll}
\hline Patient & \multicolumn{2}{l}{ Faecal Fat $(\mathrm{g} / 24 \mathrm{hr})$} & \multicolumn{2}{l}{$\begin{array}{l}\text { Schilling Test with } \\
\text { Intrinsic Factor (\%) }\end{array}$} \\
\cline { 2 - 3 } \cline { 5 - 6 } & $\begin{array}{lllll}\text { Before } \\
\text { Treatment }\end{array}$ & $\begin{array}{l}\text { After } \\
\text { Treatment }\end{array}$ & $\begin{array}{l}\text { Before } \\
\text { Treatment }\end{array}$ & $\begin{array}{l}\text { After } \\
\text { Treatment }\end{array}$ \\
\hline C.C. & 6.9 & 6.7 & 0.8 & 9.4 \\
S.E. & 36.0 & 2.0 & 11.5 & -1.7 \\
R.G. & 15.5 & 5.9 & 0.6 & 11.7 \\
\hline
\end{tabular}

Table II Effect of antibiotics on faecal fat excretion and $B_{12}$ absorption in the patients presented in Figure 2

\section{Discussion}

The high concentrations of volatile fatty acids in the jejunal contents of the patients with the stagnant loop syndrome demonstrated in this study reflect the metabolic activity of the abnormal anaerobic flora that proliferates in this condition. The pattern of organisms colonizing the jejunum in patients with the stagnant loop syndrome is well established (Drasar and Shiner, 1969; Gorbach and Tabaqchali, 1969) and the anaerobic fermentation reactions of this type of organism have been studied extensively. Patterns of production of volatile fatty acids are now being used in the taxonomic study of anaerobic organisms isolated from the gastrointestinal tract (Moore et al, 1969). The effect upon the intrajejunal volatile acid concentrations of antibiotics known to be active against these types of anaerobic flora provides further evidence for the bacterial origin of these raised volatile acid concentrations. The presence of small but significant concentrations of acetate and propionate in the jejunal contents of normal persons found in this study suggests that the sparse flora present in the normal jejunum also contributes volatile fatty acids to the jejunal fluid.

The bacterial activities causing bile salt deconjugation, vitamin $\mathbf{B}_{12}$ malabsorption, indicanuria, and deranged folate metabolism in the stagnant loop syndrome are not primary and essential metabolic activities of all anaerobic intestinal organisms and thus are not inevitably present in all patients with this condition (Tables I and II). The fermentation reactions leading to the production of volatile fatty acids are primary metabolic activities of anaerobic organisms (Wood, 1961) and are therefore likely to be a more constant indicator of anaerobic overgrowth than bile salt deconjugation, vitamin $\mathbf{B}_{12}$ malabsorption, or indole production.

The bacteriological demonstration of an overgrowth of anaerobic organisms in patients with the stagnant loop syndrome requires a sophisticated methodology. Only a few laboratories have the necessary techniques available to characterize the strictly anaerobic organisms present in the small bowel in this condition (Drasar, 1967; Gorbach, 1971). The increasing use of gas-chromatographic analysis in routine clinical biochemistry suggests that the measurement of volatile fatty acid concentrations in jejunal aspirates might be a much more convenient method of establishing an overgrowth of anaerobic organisms than a full-scale bacteriological examination using strictly anaerobic techniques.

We thank Professor C. C. Booth for advice and encouragement throughout this investigation.

References

Bryant, M. P. (1970). Normal flora-rumen bacteria. Amer. J. clin. Nutr., 23, 1440-1450.

Drasar, B. S. (1967). Cultivation of anaerobic intestinal bacteria. $J$. Path. Bact., 94, 417-427.

Drasar, B. S., and Shiner, M. (1969). Studies on the intestinal flora, Part II, Bacterial flora of the small intestine in patients with gastrointestinal disorders. Gut, 10, 812-819.

Gorbach, S. L. (1971). Intestinal microflora. Gastroenterology, 60, 1110-1129.

Gorbach, S. L., Plaut, A. G., Nahas, L., Sparknebel, G., Weinstein, L., and Levitan, R. (1967). Studies of intestinal microflora. II. Microorganisms of the small intestine and their relation to oral and fecal flora. Gastroenterology, 53, 856-867.

Gorbach, S. L., and Tabaqchali, S. (1969). Bacteria, bile and the small bowel. Gut, 10, 963-972.

Moore, W. E. C., Cato, E. P., and Holdeman, L. V. (1969). Anaerobic bacteria of the gastrointestinal flora and their occurrence in clinical infections. J. infect. Dis., 119, 641-649.

Tabaqchali, S. (1970). The pathophysiological role of small intestinal bacterial flora. Scand. J. Gastroent., Suppl. 6, 139-163.

Wood, W. A. (1961). Fermentation of carbohydrates and related compounds. In The Bacteria, Vol. II. Metabolism, edited by I. C. Gunsalus and R. Y. Stanier. Academic Press, New York and London.

Yang, M. G., Manoharan, K., and Mickelsen, O. (1970). Nutritional contribution of volatile fatty acids from the cecum of rats. $J$. Nutr., 100, 545-550. 